AgNIESZKA ŚWIĘTEK

Uniwersytet Pedagogiczny w Krakowie, Polska - Pedagogical University of Cracow, Poland

\title{
Poziom przedsiębiorczości w krajach europejskich w świetle wskaźników TEA i EEA a występujące w wybranych z nich modele kształcenia przedsiębiorczości
}

\section{Entrepreneurship in European Countries in Light of the TEA and EEA Indicators and Models of Entrepreneurship Education in Selected European Countries}

Streszczenie: Przedsiębiorczość jest istotnym czynnikiem decydującym o rozwoju społecznym i gospodarczym układów przestrzennych w różnych skalach (Płaziak, Rachwał, 2015). Współczesne pojęcie przedsiębiorczości nie doczekało się jednak zbyt wielu wskaźników, którymi można by dokonywać jego pomiaru w większych skalach przestrzennych, $\mathrm{z}$ uwzględnieniem jego szerokiego zakresu pojęciowego, co służyłoby otwarciu nowych pól badawczych. W niniejszym artykule, którego przedmiotem jest poziom przedsiębiorczości w krajach europejskich i wybrane modele edukacji w jej zakresie w krajach o najbardziej przedsiębiorczej ludności, autorka rozpoczęła pracę od analizy istniejących wskaźników wykorzystywanych przez badaczy do pomiaru przedsiębiorczości ludności. Wybrała wskaźniki przedsiębiorczości uwzględniające jej różnorodne przejawy i dokonała analizy przestrzennego zróżnicowania ich poziomu w Europie (wskaźniki GEM: Globalnego Monitora Przedsiębiorczości - TEA i EEA). $\mathrm{Na}$ tej podstawie wskazała kraje europejskie o najbardziej przedsiębiorczej ludności. Zakładając kluczową rolę edukacji w zakresie przedsiębiorczości w kształtowaniu postawy przedsiębiorczej ludności, dokonała następnie analizy systemów edukacji w zakresie przedsiębiorczości w krajach najbardziej przedsiębiorczych (wg wcześniejszych wyników analizy wskaźnika TEA i EEA). Analiza wykazała, że kraje o najwyższym poziomie przedsiębiorczości ludności (Estonia, Łotwa, Szwecja) cechują odmienne, wysoko rozwinięte systemy kształcenia w zakresie przedsiębiorczości, których najistotniejsze rozwiązania przedstawiono w artykule. Autorka zamyka pracę wskazaniem tych rozwiązań spośród nich, które można wykorzystać w Polsce w celu podniesienia jakości kształcenia przedsiębiorczości.

Abstract: Entrepreneurship is an important factor determining the social and economic develop-
ment of spatial systems of different scales (Płaziak, Rachwal 2015). However, the contemporary notion
of entrepreneurship has not yet seen a fair number of indicators potentially measuring it in larger spatial
dimensions, taking into account a broad range of concepts and ideas it entails, which could help to open
up new research areas.In the paper devoted to the advancement of entrepreneurship in the European
countries and to selected models of education for enterprise in countries with the most entrepreneur- 
ial population, the author begins with analysing the existing indicators used by researchers to measure entrepreneurship in population. She has chosen indicators which account for its various manifestations and analysed spatial diversification of entrepreneurship level in Europe (the Global Entrepreneurship Monitoring indicators TEA and EEA). On this basis, she listed the European countries with the most entrepreneurial population. Assuming the key role of education for entrepreneurship in developing and shaping entrepreneurial attitudes in the population, as the next stage, she analysed the systems educating for entrepreneurship in the most entrepreneurial countries (according to the earlier results from analysing the TEA and EEA indicators). The analysis showed that the countries with the most entrepreneurial population (Estonia, Latvia and Sweden) are characterised by different, advanced systems of educating for entrepreneurship and the key solutions applied in the systems are presented in the paper. The author concluded her paper with a presentation of solutions potentially implementable in Poland in order to improve the quality of entrepreneurship education.

Słowa kluczowe: edukacja w zakresie przedsiębiorczości; EEA; GEM; modele kształcenia przedsiębiorczości; TEA; wskaźnik przedsiębiorczości

Keywords: EEA; entrepreneurship education; entrepreneurship indicator; GEM; models of entrepreneurship education; TEA

Otrzymano: 19 listopada 2017

Received: 19 November 2017

Zaakceptowano: 5 lipca 2018

Accepted: 5 July 2018

Sugerowana cytacja/Suggested citation:

Świętek, A. (2018), Poziom przedsiębiorczości w krajach europejskich w świetle wskaźników TEA i EEA a występujące w wybranych z nich modele kształcenia przedsiębiorczości. Przedsiębiorczość Edukacja [Entrepreneurship - Education], 14, 445-459. DOI: 10.24917/20833296.14.30

\section{Wstęp}

„Przedsiębiorczość jest powszechnie traktowana jako jeden z podstawowych czynników rozwoju społecznego i gospodarczego w układach przestrzennych o różnej skali (krajowych, regionalnych, lokalnych)" (Płaziak, Rachwał, 2015: 37). Nie dziwi więc, że jako domniemany czynnik sprawczy rozwoju społeczno-ekonomicznego staje się dla badaczy coraz bardziej interesującym przedmiotem analiz. Zakres tematyczny prac związanych z przedsiębiorczością, prowadzonych przez współczesnych badaczy jest bardzo szeroki, a wynika z różnorodnych jej koncepcji. Tradycyjnie przedsiębiorczość rozpatrywana jest jako wyznacznik innowacyjności w przedsiębiorstwach (Karpacz, 2011). Nowszymi kierunkami badań są np.: przedsiębiorczość korporacyjna (Czerniachowicz, 2011; Lichtarski, 2003), przedsiębiorczość „niezależna” (Lichtarski, 2003), intelektualna (Kwiatkowski, 2000), czy przedsiębiorczość garażowa (Glinka, Gudkova, 2011). Badacze podejmują prace nad znaczeniem przedsiębiorczości w rozwoju obszarów o różnej wielkości (np. Makieła, 2007; Strojny, 2010; Salamon, 2009) i analizują relacje pomiędzy przedsiębiorczością a innymi zjawiskami społeczno-ekonomicznymi. Istotne są analizy relacji przedsiębiorczości z wchodzeniem na rynek pracy, czego owocem są prace empiryczne i teoretyczny model ich zależności (Zioło, 2007).

Dla przedmiotu badań autorki szczególnie znaczące są analizy roli edukacji w zakresie przedsiębiorczości w przygotowywaniu młodzieży do dorosłego życia. Spośród licznych 
prac w tym nurcie na szczególną uwagę zasługują prace dotyczące postaw kształtowanych na lekcjach przedsiębiorczości (Rachwał, 2005), cech przedsiębiorczych, które można wykształcić w toku edukacji szkolnej (Maślanka, 2008), wpływu edukacji na postawy przedsiębiorcze (Sołoducho-Pelc, 2007; Daszkiewicz, 2014) i wreszcie prace, w których autorzy dowodzą (rozważaniami teoretycznymi i dowodami empirycznymi) znaczenia edukacji z przedsiębiorczości i jej wpływu na rozwój gospodarczy (np. Skubiak, 2014; Wach, 2013; Brzozowski, 2013).

Intensywność prac badaczy w zakresie przedsiębiorczości przyniosła zmiany w jej rozumieniu, a przez to mnogość jej definicji. Pierwotna definicja przedsiębiorczości ewoluowała i nie ogranicza się już do znaczenia wyłącznie ekonomicznego. Niestety, we współczesnych publikacjach nadal można jednak spotkać jej pierwotne rozumienie, które autorka przytacza za aktualną Internetowa encyklopedia PWN: „Przedsiębiorczość - (ekon.) umiejętność doboru i zaangażowania w działalności gospodarczej, prowadzonej w warunkach niepewności, czynników wytwórczych w sposób zapewniający zysk jednemu przedsiębiorcy lub grupie przedsiębiorczych osób”. Nowe definicje przedsiębiorczości podkreślają jej znacznie szerszy zakres, uwzględniający jej różnorodne składowe i ujmujący ją jako zespół pewnych cech osobowych. Nie istnieje jedna definicja przedsiębiorczości, co do której autorzy byliby zgodni. Istnieje jednak kilka definicji integrujących aktualne stanowisko badaczy na temat przedsiębiorczości, spośród których za wykładnię w niniejszej pracy posłuży autorce definicja T. Rachwała: „Przedsiębiorczość - zespół cech osobowych, takich jak aktywność, zapał do pracy, inicjatywa, kreatywność [...], pewność siebie, samodyscyplina, uczciwość, skłonność do wyważonego ryzyka [...]. Cechy te pozwalają nie tylko dobrze prowadzić przedsiębiorstwo, tj. być dobrym przedsiębiorcą ( $\mathrm{z}$ czym pojęcie to jest często utożsamiane), ale także aktywnie uczestniczyć w życiu społeczno- gospodarczym" (Rachwał, 2004: 169).

Tak rozumiane, współczesne pojęcie przedsiębiorczości nie doczekało się dotąd zbyt wielu wskaźników, którymi można by dokonywać jego pomiaru. Dokonanie takowego, w większych skalach przestrzennych, służyłoby zdaniem autorki otwarciu nowych pól badawczych, w szczególności w zakresie wzajemnego warunkowania przedsiębiorczości i wskaźników rozwoju społeczno-ekonomicznego. Analiza ich korelacji i związków przyczynowo-skutkowych mogłaby prowadzić z kolei do dalszego wnioskowania na temat uwarunkowań poziomu przedsiębiorczości w różnych skalach przestrzennych i jej wpływu na poziom poszczególnych aspektów poziomu i jakości życia ludności oraz kondycji gospodarki.

Przykładem badań wpisujących się w tak zakreślone pole badawcze jest niniejsza praca, której przedmiotem jest poziom przedsiębiorczości w krajach europejskich i wybrane modele edukacji w jej zakresie w krajach o najbardziej przedsiębiorczej ludności. $\mathrm{W}$ artykule autorka prezentuje podejmowane $\mathrm{w}$ ramach wskazanego przedmiotu kroki badawcze, będące realizacją kolejnych celów badawczych. Pierwszym celem badań przedstawionych w artykule była analiza wskaźników wykorzystywanych przez badaczy do pomiaru przedsiębiorczości ludności. Drugim celem był wybór spośród nich wskaźnika przedsiębiorczości uwzględniającego jej różnorodne przejawy, zgodnie z przyjętą przez autorkę, szeroką i nowoczesną definicją przedsiębiorczości. Trzecim celem było wskazanie krajów o najbardziej przedsiębiorczej ludności, określone w wyniku analizy zróżnicowania poziomu wybranego wskaźnika. Czwartym celem była analiza systemów edukacji w zakresie przedsiębiorczości w krajach najbardziej przedsiębiorczych, a na jej 
podstawie - wskazanie w analizowanych, wybranych systemach tych rozwiązań, które są możliwe do wykorzystania w Polsce dla podniesienia jakości kształcenia w zakresie przedsiębiorczości. Dla osiągnięcia tych celów autorka przeprowadziła więc: kwerendę literatury, analizę przestrzennego zróżnicowania poziomu wskaźnika przedsiębiorczości oraz analizę porównawczą systemów kształcenia.

\section{Wskaźniki przedsiębiorczości - dysonans definicji i sposobów pomiaru}

W literaturze przedmiotu autorzy podkreślają, że wskaźniki służące do pomiaru przedsiębiorczości dzielą się zasadniczo na dwie grupy, służące do „pomiaru ducha przedsiębiorczości” oraz „pomiaru efektów przedsiębiorczości” (Raczyk, 2009; Siuta-Tokarska, 2013). W pierwszej grupie znajdują się wskaźniki związane z inicjatywami podjęcia działalności gospodarczej, takie jak „aktywność startowa” wyrażająca się działaniami zorientowanymi na założenie nowego przedsiębiorstwa, czy „aktywność przerwana” rozumiana jako próba założenia działalności, niezakończona sukcesem (Reynolds, 2000). W grupie tej „analizy są związane zasadniczo z badaniami ankietowymi wybranych grup osób lub populacji” (Siuta-Tokarsa, 2013: 93). W „pomiarze efektów przedsiębiorczości” natomiast analizie podlegają liczby różnego typu przedsiębiorstw odniesione do populacji ludzkiej lub ogółu podmiotów gospodarczych. Konstruowane na tej podstawie wskaźniki opierają się na danych zbieranych przez statystykę publiczną (Raczyk, 2009). Do stosowanych w literaturze wskaźników należących do tej grupy zaliczono:

- liczbę podmiotów gospodarczych (np. podmiotów sektora małych i średnich przedsiębiorstw na 1000 mieszkańców ogółem lub w wieku produkcyjnym),

- wskaźnik przedsiębiorczości (liczbę przedsiębiorców) na 1000 ludności w wieku produkcyjnym,

- strukturę wielkościową przedsiębiorstw (udział \% mikroprzedsiębiorstw w ogóle przedsiębiorstw, struktura zatrudnienia w przedsiębiorstwach według klas wielkości przedsiębiorstw),

- wskaźniki zmian liczby przedsiębiorstw (np. nowo powstałych lub bankrutujących przedsiębiorstw, przyrost „netto” przedsiębiorstw - różnica między podmiotami zarejestrowanymi a wyrejestrowanymi w stosunku do ogółu liczby przedsiębiorstw lub mieszkańców),

- wskaźnik stabilizacji sektora prywatnego (stosunek liczby przedsiębiorstw zarejestrowanych do liczby przedsiębiorstw wyrejestrowanych w danym roku),

- udział przedsiębiorstw w zakresie tworzenia wartości dodanej w sektorze przedsiębiorstw według klas ich wielkości,

- skłonność przedsiębiorstw do eksportu (\% przedsiębiorstw eksportujących do całkowitej liczby przedsiębiorstw w danej klasie wielkości) (Sołtys, Dorocki, 2016; Raczyk, 2009; Siuta-Tokarska, 2013; Hryniewicz, 1998; Kowalczyk, Wilk 1994; Gorzelak, Jałowiecki, 1996; Czyżewski i in. 2001).

Istniejące wskaźniki służące pomiarowi przedsiębiorczości w większych skalach przestrzennych nie odpowiadają jej współczesnemu, szerokiemu rozumieniu. Dotyczy to obu grup wskaźników, zarówno w zakresie „pomiaru ducha przedsiębiorczości”, jak i „pomiaru efektów przedsiębiorczości" (na marginesie należy zaznaczyć, że sformułowania te, a w szczególności pierwsze z nich, są mało trafne). Omawiane wskaźniki uwzględniają bowiem jedynie jeden aspekt przedsiębiorczości - związany z zakładaniem i prowadzeniem 
działalności gospodarczej. Pomijają zatem całą sferę przedsiębiorczości wewnętrznej, czyli działania przedsiębiorcze podejmowane przez osoby niepracujące na własny rachunek.

Wyjątkiem pod tym względem są wskaźniki tworzone w ramach GEM (ang. Global Entrepreneurship Monitor, pol. Globalny Monitor Przedsiębiorczości). GEM to obecnie największy (jeśli chodzi o zasięg przestrzenny), naukowy projekt badawczy z przedsiębiorczości na świecie. Został on zainicjowany przez London Business School i Babson College, a obecnie jest prowadzony przez World Economic Forum, współpracujące z krajowymi zespołami badawczymi. W Polsce instytucjami współpracującymi w ramach GEM są PARP (Polska Agencja Rozwoju Przedsiębiorczości) i Uniwersytet Ekonomiczny w Katowicach. Przedmiotem badań w ramach projektu jest przedsiębiorczość we wczesnym stadium rozwoju, a ich celem jest pomiar różnic w poziomie przedsiębiorczości krajów, poznanie czynników determinujących charakter i poziom aktywności przedsiębiorczej w poszczególnych krajach, by na tej podstawie dokonać implikacji wyników badań w krajowe polityki społeczno-gospodarcze na rzecz wspierania przedsiębiorczości (Tarnawa i in., 2016). Model rozwoju gospodarczego GEM (ryc. 1) zakłada bowiem, że różne przejawy aktywności przedsiębiorczej (zarówno sektora indywidualnego komercyjnego i społecznego, jak i intraprzedsiębiorczości) powodują „efekty przedsiębiorczości” w postaci miejsc pracy i wartości dodanej ich działalności, co ma pozytywny wpływ na rozwój społeczno-gospodarczy państw (a przez to na poziom życia ludności). Społeczne, kulturowe, polityczne, ekonomiczne i kontekstualne tło wraz z poziomem rozwoju społeczno-gospodarczego tworzą natomiast układ wzajemnie warunkujących się zależności rozwoju przedsiębiorczości.

GEM opiera się na jednolitej metodologii pozyskiwania danych. Zakłada przeprowadzenie badania ilościowego (metodą CATI) na minimalnej próbie statystycznej 2000

Ryc. 1. Model rozwoju gospodarczego GEM

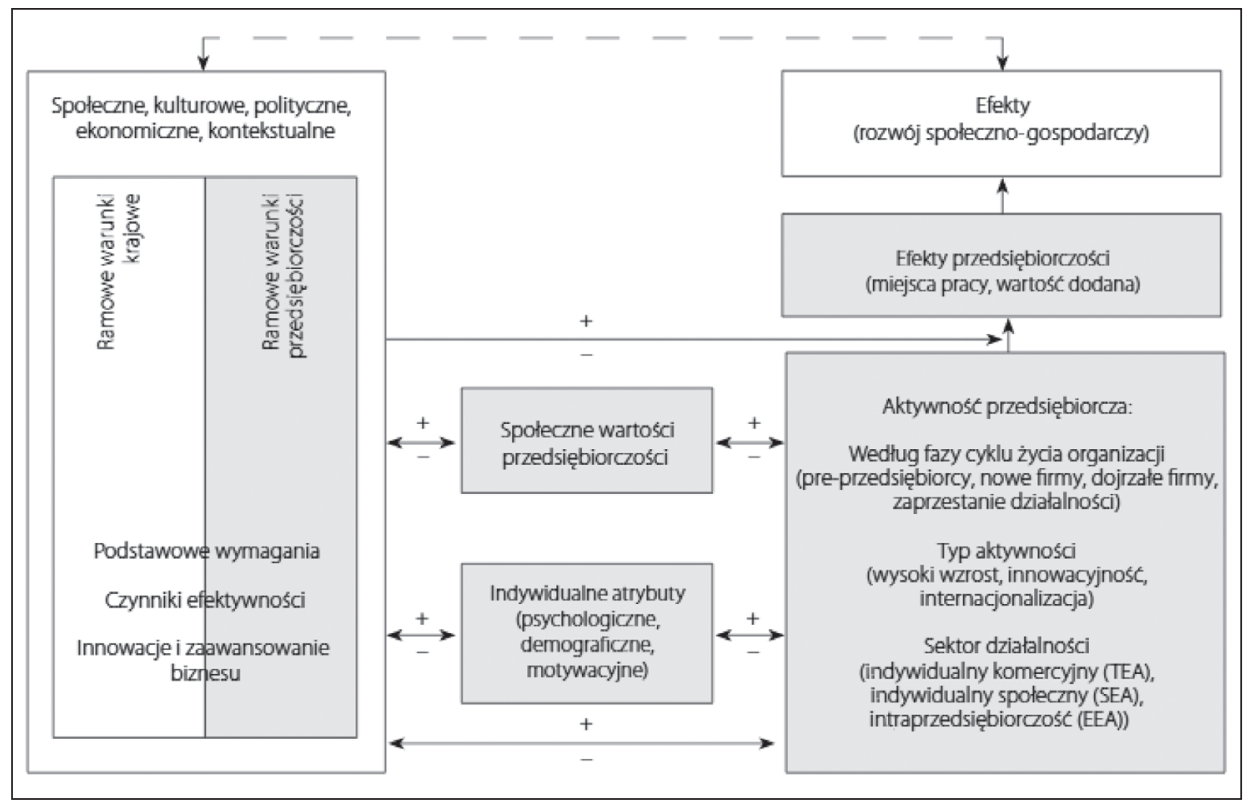

Źródło: Singer, Amoros, Moska (2015: 20) 
dorosłych respondentów (APS) oraz minimum 36 indywidualnych wywiadów z ekspertami z różnych dziedzin, bezpośrednio lub pośrednio związanych z przedsiębiorczością (NES). Grupa ekspertów w każdym kraju wybierana jest na podstawie tych samych kryteriów (wg rodzaju działalności - naukowiec, manager itd.) i doświadczenia w prowadzeniu działalności). Od roku 2015 badaniami GEM objęte są 62 kraje świata (w tym niemal wszystkie kraje europejskie). Na podstawie uzyskanych danych konstruowane są wskaźniki poziomu przedsiębiorczości, z których najważniejsze to: TEA - Total Early-stage Entrepreneurial Activity - oraz EEA - Employee Entrepreneurial Activity (Tarnawa i in., 2016).

\section{Poziom przedsiębiorczości w Polsce na tle Europy}

w świetle wskaźników TEA i EEA

Pierwszym podstawowym wskaźnikiem pomiaru przedsiębiorczości GEM wybranym przez autorkę do analizy jest TEA, tzw. „całkowita przedsiębiorczość we wczesnym stadium”. Posłuży on wskazaniu najbardziej przedsiębiorczych społeczeństw z punktu widzenia pierwszego aspektu przedsiębiorczości, jakim jest aktywność w zakresie zakładania i rozwijania nowego przedsiębiorstwa. Wskaźnik TEA określa udział (\%) osób, które są zaangażowane w zakładanie działalności gospodarczej lub prowadzenie nowego przedsiębiorstwa, działającego do 3,5 roku w ogóle ludności w wieku produkcyjnym (18-64 lat). Do osób tych zalicza się dwie grupy:

1. „rodzących się przedsiębiorców” (nascent entrepreneurs), czyli osoby, które:

- w momencie sondażu usiłują samodzielnie lub z partnerami założyć własną firmę,

- w ciągu ostatnich dwunastu miesięcy podjęły jakiekolwiek kroki w celu utworzenia nowej firmy,

- dążą do zajęcia pozycji właścicielskich w jakimś przedsiębiorstwie,

- w ciągu ostatnich trzech miesięcy nie wypłacały jeszcze pełnoetatowego wynagrodzenia pracownikom;

2. „nowych przedsiębiorców” (new entrepreneurs), czyli osoby, które:

- są właścicielami lub współwłaścicielami i uczestniczą w zarządzaniu tym przedsiębiorstwem,

- nie otrzymują wynagrodzenia z udziału w zyskach i świadczeń rzeczowych dłużej niż 3,5 roku (Tarnawa i in., 2016).

Zgodnie z wynikami badań GEM w Europie, w 2014 r. poziom wskaźnika TEA mieścił się w granicach 4-13,3\%. Największy udział zakładających przedsiębiorstwa i nowych przedsiębiorców w ogóle ludności w wieku produkcyjnym, powyżej 10\%, występował w pięciu krajach. Były to: Łotwa (13,3\%), Estonia (12,6\%), Słowacja (11,3\%), Litwa (10,4\%) i Rumunia (10,1\%). Najniższy z kolei poziom wskaźnika TEA występował we Włoszech (4,0\%). Niskie wartości przyjmował on również w większości pozostałych krajów „starej Unii”, np. w Danii (5,2\%), Francji (5,4\%), Belgii $(5,4 \%)$ i w Niemczech (5,5\%). Poziom wskaźnika TEA osiągał wyższe wartości w krajach Europy Środkowo-Wschodniej i Północnej niż w krajach Europy Zachodniej i Południowej. W Polsce w 2014 r. udział osób przedsiębiorczych w myśl wskaźnika TEA wynosił 9,4\% populacji w wieku produkcyjnym, co uplasowało ją na 9 miejscu wśród krajów europejskich.

Przyczyny takiego zróżnicowania leżą, zdaniem autorki, w poziomie rozwoju społeczno-ekonomicznego wskazanych krajów i mogą mieć różnorodne źródła. W krajach rozwiniętych występuje wysoki stopień zaspokojenia potrzeb ludności przez oferowane 
Ryc. 2. Poziom wskaźnika TEA w 28 krajach europejskich w 2014 r.

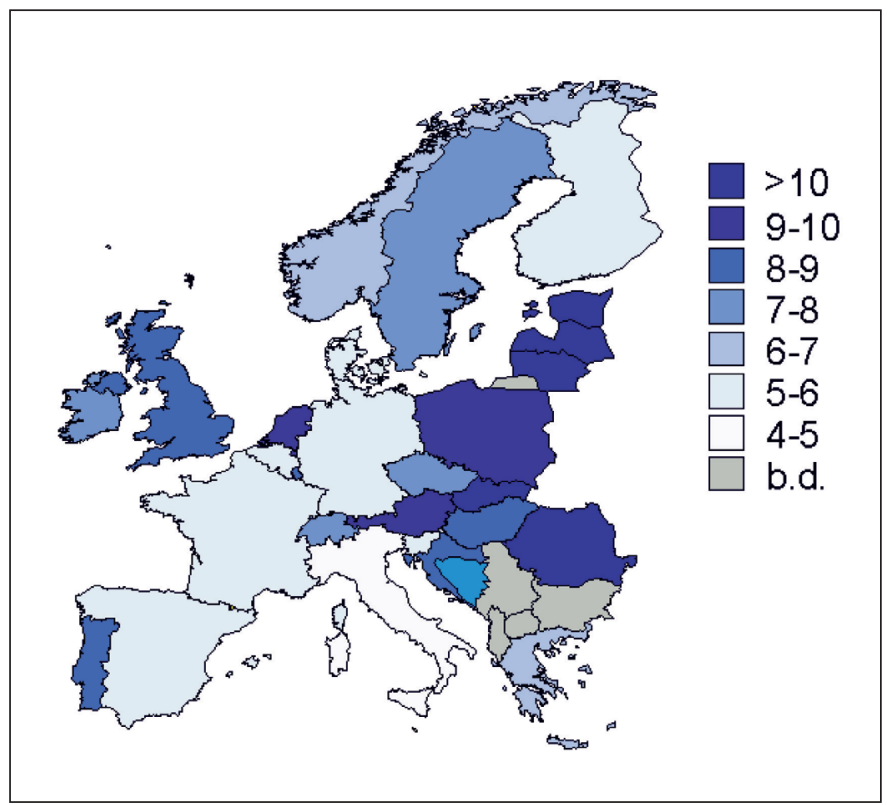

Źródło: opracowanie własne na podstawie danych Global Entrepreneurship Monitor (GEM)

im na rynku dobra i usługi przez lepiej wyspecjalizowane, silnie ze sobą konkurujące przedsiębiorstwa, co utrudnia młodym przedsiębiorcom wejście na rynek. Jest ono trudniejsze niż wchodzenie na młodsze i bardziej chłonne rynki krajów słabiej rozwiniętych. Lepsza sytuacja startowa młodych ludzi wchodzących na rynek pracy w zamożniejszych krajach paradoksalnie opóźnia w czasie podjęcie decyzji o usamodzielnieniu (czego przykładem jest późne zakładanie rodziny i pozostawanie na utrzymaniu rodziców - w krajach Europy Południowej niemal do 30 r.ż.) i może powodować niechęć do podejmowania trudu i ryzyka związanego z rozpoczynaniem własnej działalności gospodarczej. Na tych kilku wnioskach autorka poprzestanie, gdyż wymagają one osobnej, szerokiej analizy i winny stać się przedmiotem dalszej pracy badawczej.

W nawiązaniu do przytoczonej na początku artykułu definicji przedsiębiorczości dla pełnej analizy jej przestrzennego zróżnicowania należy również uwzględnić inne jej przejawy niż te związane z samodzielnym zakładaniem działalności gospodarczej. Aspekt taki uwzględnia wskaźnik EEA, a zatem wskaźnik „intraprzedsiębiorczości”, zwanej przedsiębiorczością organizacyjną lub korporacyjną. EEA to udział procentowy osób w ogóle populacji obywateli danego kraju w wieku 16-64 lata, które odgrywają wiodącą rolę w przedsiębiorczości organizacyjnej. Osoby te wykazują się tworzeniem przedsięwzięć przedsiębiorczych nie na własną rękę, lecz w imieniu i na rzecz własnego pracodawcy. Do takiej działalności zalicza się bycie silnie zaangażowanym lub pełnienie wiodącej roli w powstawaniu i wprowadzaniu w życie nowych działań, np. wymyślanie i wprowadzanie na rynek nowych produktów i usług, otwarcie nowego oddziału firmy lub jej filii. Wskaźnik EEA jest zatem wyjątkowy, gdyż bada te przejawy przedsiębiorczości, które nie są związane z prowadzeniem własnej działalności gospodarczej i dotąd w badaniach na szeroką skalę nie występowały (Europe’s Hidden Entrepreneurs..., 2016). 
Ryc. 3. Poziom wskaźnika EEA w 28 krajach europejskich w 2014 r.

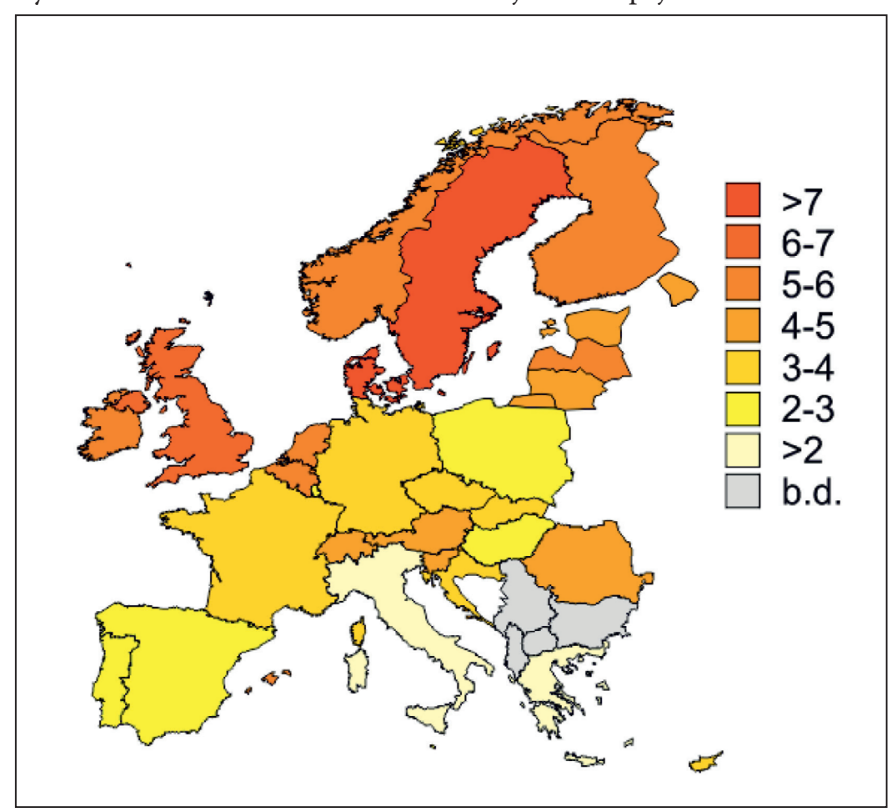

Źródło: opracowanie własne na podstawie danych GEM

W Europie poziom wskaźnika „intraprzedsiębiorczości” wykazuje silne zróżnicowanie regionalne. W krajach Europy Północnej jest wyższy niż w krajach Europy Południowej. Największym udziałem osób przedsiębiorczych pracujących nie na własny rachunek odznaczają się Szwecja (9,1\%) i Dania (9,0\%). Powyżej 6\% przedsiębiorców wewnątrz organizacji stwierdzono jeszcze tylko w Wielkiej Brytanii (6,5\%). W pozostałych krajach poziom „intraprzedsiębiorczości” jest niższy i mieści się w granicach 2-5\%. Najmniejszą przedsiębiorczością wewnętrzną wykazują się trzy kraje basenu Morza Śródziemnego: Włochy $(0,7 \%)$, Grecja $(1,1 \%)$ i Hiszpania $(2,0 \%)$.

Analiza zróżnicowania przestrzennego poziomu wskaźników TEA i EEA wskazuje na rozbieżności w poziomie przedsiębiorczości ludności w krajach europejskich, w zależności od przyjętego do analizy aspektu przedsiębiorczości. Fakt ten utwierdził autorkę w przekonaniu, że tylko łączna analiza wskaźników TEA i EEA pozwoli na uzyskanie pełniejszego obrazu zróżnicowania poziomu przedsiębiorczości ludności w krajach europejskich, zgodnie z przyjętą szeroką definicją przedsiębiorczości. Postawa przedsiębiorcza przejawia się bowiem zarówno w dążeniu do zakładania własnej działalności gospodarczej i jej rozwijania w początkowej fazie działalności, jak i w podejmowaniu działań mających na celu dynamiczny rozwój organizacji przez zatrudnione w nich, decyzyjne jednostki (choć i w innych aspektach nieuwzględnionych w analizowanych wskaźnikach...).

Najwyższym odsetkiem przedsiębiorczej ludności w krajach europejskich w roku 2014 wg połączonych poziomów wskaźnika TEA i EEA wykazały się kraje Europy Północnej: Estonia (15,8\%), Szwecja (15,3\%) i Łotwa (14,8\%). Powyżej 13\% ludności przedsiębiorczej występowało również w większości krajów północnych: Danii, Wielkiej Brytanii, Norwegii, Litwie oraz na Słowacji. Średni odsetek osób przedsiębiorczych w ogólne ludności w wieku produkcyjnym w 28 krajach europejskich podlegających analizie wynosił 
Ryc. 4. Poziom wskaźników TEA i EEA w 28 krajach europejskich w 2014 r.

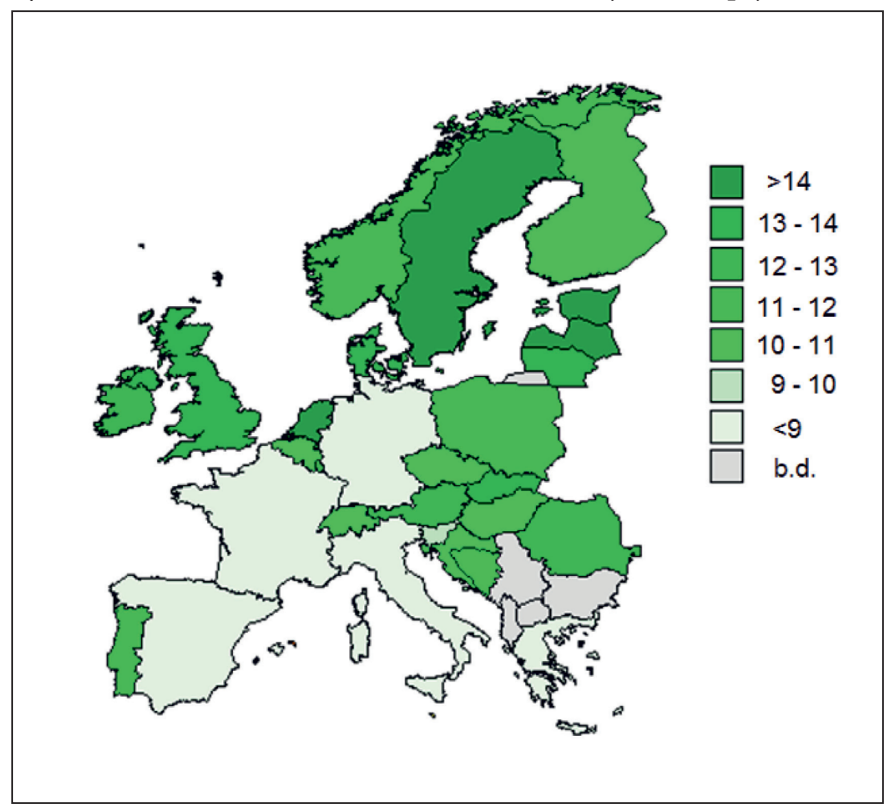

Źródło: opracowanie własne na podstawie danych GEM

11,43\%. Przedstawicielami grupy państw „średnich” z punktu widzenia udziału ludności przedsiębiorczej jest większość państw Europy Środkowo-Wschodniej, w tym Polska (11,40\%). Krajami o najmniejszym odsetku przedsiębiorczej ludności (poniżej 9\%) są natomiast w większości kraje basenu Morza Śródziemnego: Hiszpania, Francja, Włochy, Grecja oraz Niemcy.

Na końcu analizy autorka pragnie podkreślić, że ma świadomość daleko idącej niedoskonałości (a dokładniej mówiąc - niekompletności) analizowanych wskaźników z punktu widzenia definicji przedsiębiorczości. Najważniejszym, zdaniem autorki, brakiem jest nieuwzględnianie „intraprzedsiębiorczości” przedsiębiorców prowadzących działalność gospodarczą powyżej 3,5 roku. Wskaźnik TEA odnoszący się do aspektu przedsiębiorczości związanego z działalnością gospodarczą uwzględnia bowiem za przedsiębiorcze osoby dążące do założenia własnej działalności gospodarczej i osoby ją prowadzące przez okres do 3,5 roku. Wskaźnik EEA uwzględnia natomiast osoby wykazujące się przedsiębiorczością wewnątrz przedsiębiorstw, w których są zatrudnione. W żadnej z grup badawczych nie uwzględniono natomiast przedsiębiorców, którzy wykazują się przedsiębiorczą postawą w prowadzeniu własnej działalności gospodarczej, funkcjonującej na rynku dłużej niż 3,5 roku. Hipotetyczny wskaźnik OEA - Owner Entrepreneurial Activity - jak proponuje go nazywać autorka - byłby więc udziałem procentowym przedsiębiorców prowadzących działalność gospodarczą powyżej 3,5 roku w ogóle osób w wieku produkcyjnym (aby był rozłączny z TEA i EEA, a przez to porównywalny z nimi i możliwy do scalenia we wskaźnik TEA + EEA + OEA), wykazujących się przedsiębiorczą postawą w prowadzeniu swojego przedsiębiorstwa. Nie należałoby zaliczać do tej grupy wszystkich przedsiębiorców, lecz wyłącznie tych rozwijających działalność w różnorodnych zakresach (np. zwiększających zasięg przestrzenny swego rynku zbytu, otwierających nowe filie czy 
wprowadzających na rynek nowe produkty i usługi). Przedstawiona propozycja jest oczywiście jedynie pomysłem, wymagającym dalszej pracy, którą należałoby rozpocząć od odpowiedzi na zasadnicze pytanie: co dokładnie znaczy „rozwijać działalność gospodarczą” i jakimi składowymi zmiennymi te aspekty mierzyć. Kwestia niedostatków istniejących wskaźników przedsiębiorczości i potencjalnych nowych wskaźników dopełniających jej pomiar wymagają osobnej, szerokiej analizy.

Niemniej jednak należy podkreślić, że w ramach projektu GEM po raz pierwszy zbadano ilościowo aspekt przedsiębiorczości inny niż związany z działalnością gospodarczą, a wyniki łącznej analizy wskaźników TEA i EEA pozwalają na wyciągnięcie wstępnych wniosków dotyczących zróżnicowania poziomu przedsiębiorczości w poszczególnych krajach europejskich. Wyniki te mogą stanowić punkt odniesienia do analiz w innych zakresach tematycznych. Jednym z takich zakresów, który pragnie zaznaczyć w niniejszym artykule autorka, jest kwestia edukacji z przedsiębiorczości.

\section{Modele edukacji z przedsiębiorczości w Europie}

Na podstawie dokonanej kwerendy literatury autorka ustaliła, że edukacja w zakresie przedsiębiorczości wpływa na podniesienie poziomu przedsiębiorczości ludności w danym kraju. Tezę tę postanowiła zweryfikować, zestawiając wyniki analizy przestrzennego zróżnicowania wskaźników przedsiębiorczości z analizą modeli edukacji w zakresie przedsiębiorczości w poszczególnych krajach europejskich.

Zgodnie z wynikami analiz zakresu treści i celów kształcenia podstaw programowych kształcenia ogólnego, w Europie przyjęto trzy różne strategie kształcenia w zakresie przedsiębiorczości (Entrepreneurship Education..., 2012; Sadowska, 2016). W wielu krajach Europy Północnej przedsiębiorczość realizowana jest zgodnie z poświęconą wyłącznie jej, specjalną strategią. Ma to miejsce w Szwecji, Norwegii, Danii, Belgii, Holandii, Walii (części Wielkiej Brytanii), Estonii i na Litwie. Drugim modelem jest uwzględnianie przedsiębiorczości jako elementu większej strategii edukacyjnej. Przykładem może być uwzględnienie przedsiębiorczości w Polsce, Czechach czy na Słowacji jako obowiązkowego przedmiotu kształcenia ogólnego przygotowującego młodzież, obok innych przedmiotów, do dorosłego życia. Trzecim modelem kształcenia w zakresie przedsiębiorczości jest realizacja jej celów pojedynczymi inicjatywami edukacyjnymi, co ma miejsce w różnych częściach Europy: w Portugalii, Rumunii, Irlandii, Anglii i na Łotwie. Jak wskazuje raport Euridice, w Europie są również kraje, w których do roku 2012 nie występowały konkretne strategie kształcenia w zakresie przedsiębiorczości. Zaliczyć można do nich Niemcy, Francję czy Włochy (Entrepreneurship Education..., 2012).

Porównanie przestrzennego zróżnicowania poziomu wskaźnika przedsiębiorczości w Europie (ryc. 4) z mapą przyjętych modeli kształcenia w zakresie przedsiębiorczości (ryc. 5) pozwala na wskazanie pewnych prawidłowości. W państwach o wyższym odsetku osób przedsiębiorczych (wg wskaźników TEA i EEA), skupionych w Europie Północnej, najczęściej występują konkretne strategie kształcenia w zakresie przedsiębiorczości. W państwach o średnim poziomie przedsiębiorczości, czyli krajach Europy ŚrodkowoWschodniej, najczęściej przedsiębiorczość występuje jako cześć większej strategii edukacyjnej. Natomiast we Włoszech, Niemczech i Francji, gdzie nie ma strategii edukacji w zakresie przedsiębiorczości, udział przedsiębiorczej ludności w ogóle ludności jest jednym z najmniejszych. Od opisanej prawidłowości występują oczywiście wyjątki, którymi 
Ryc. 5. Narodowe strategie i inicjatywy włączenia przedsiębiorczości w systemy edukacji (stan na 2012 rok)

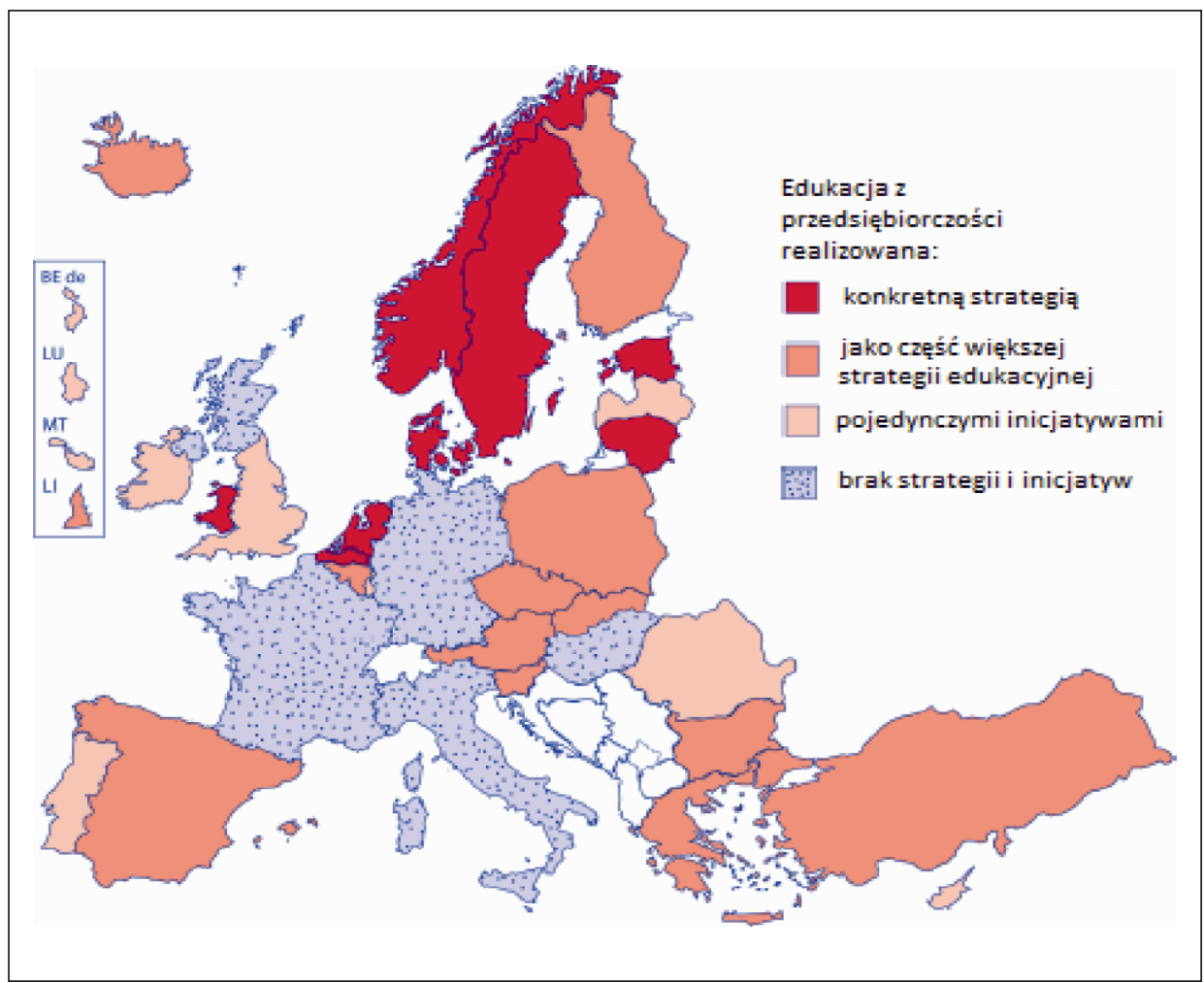

Źródło: Entrepreneurship Education... (2012)

są np. Grecja i Hiszpania - kraje o bardzo niskim poziomie wskaźnika przedsiębiorczości, w których występuje ona jako część większej strategii kształcenia.

Istotniejszym niż wskazywanie przyczyn niepowodzeń kształcenia w zakresie przedsiębiorczości jest skupienie się na rozwiązaniach edukacyjnych w zakresie przedsiębiorczości w krajach, w których udział przedsiębiorczej ludności jest najwyższy. Świadczyć to może o skuteczności przyjętych tam rozwiązań, których transfer mógłby stanowić wkład w rozwój polskiej edukacji z przedsiębiorczości. Autorka postanowiła więc dokonać analizy systemów kształcenia w zakresie przedsiębiorczości w krajach o największym udziale przedsiębiorczej ludności, za które uznano (wg wskaźników TEA i EEA): Estonię, Łotwę i Szwecję.

W Estonii szczególne znaczenie przedsiębiorczości w przygotowaniu młodych ludzi do dorosłego życia usankcjonowano porozumieniem o współpracy na rzecz jej rozwoju, podpisanym przez estońskiego ministra edukacji i nauki, ministra gospodarki i komunikacji, Izbę Przemysłowo-Handlową, Krajowe Centrum Egzaminów i Kwalifikacji oraz Estońską Fundację Przedsiębiorczość w dniu 7 października 2010 r. Na podstawie zawartego porozumienia przygotowano „program promocji edukacji w zakresie przedsiębiorczości”, który został wprowadzony do estońskiej podstawy programowej. Cele kształcenia $\mathrm{w}$ zakresie przedsiębiorczości wplecione zostały w programy kształcenia innych 
przedmiotów na wszystkich etapach edukacyjnych w ramach międzyprzedmiotowego programu (rodzaju ścieżki edukacyjnej) „Inicjatywa obywatelska i przedsiębiorczość”. Prócz tego, wybrane cele kształcenia w zakresie przedsiębiorczości realizowane są na obowiązkowym przedmiocie edukacja obywatelska na II i III etapie edukacyjnym (który to przedmiot jest odpowiednikiem polskiej wiedzy o społeczeństwie). Treści z przedsiębiorczości są dodatkowo rozszerzane na przedmiocie edukacja ekonomiczna i biznesowa na III etapie edukacyjnym. Cele kształcenia z przedsiębiorczości zawarte w podstawach programowych ww. przedmiotów są bardzo zbliżone do tych zawartych w polskiej podstawie programowej. Dużą wagę przywiązuje się do wsparcia merytorycznego nauczycieli. Dobrej jakości materiały dydaktyczne do kształcenia w zakresie przedsiębiorczości dostępne są dla nauczycieli przedsiębiorczości na oficjalnych rządowych stronach internetowych (Entrepreneurship Education..., 2012).

Podobna jest sytuacja edukacji z przedsiębiorczości w Szwecji. Kształcenie w zakresie przedsiębiorczości również traktowane jest w tym kraju jako priorytetowe, o czym świadczy uwzględnienie jej w szwedzkiej ustawie budżetowej. Wydzielono w niej konkretne fundusze na inicjatywy w zakresie wsparcia edukacji z przedsiębiorczości. Przedsiębiorczość w szwedzkim systemie edukacyjnym występuje jako osobny przedmiot o nazwie ekonomia na III etapie kształcenia. Podobnie jak w Estonii, stosowana jest tu strategia uwzględniania treści z zakresu przedsiębiorczości na wielu innych przedmiotach, by towarzyszyły one uczniowi w toku całej edukacji. Cele kształcenia w zakresie przedsiębiorczości wplecione są więc w programy nauczania innych przedmiotów na wszystkich etapach edukacyjnych. Przykładowo na I i II drugim etapie edukacyjnym treści z przedsiębiorczości realizowane są na przedmiotach: technologia (wśród uczniów w wieku 1213 lat) czy rzemiosło (wśród uczniów w wieku 15-16 lat). Podobnie jak w Estonii, cele kształcenia z przedsiębiorczości są bardzo zbliżone do celów zawartych w polskiej podstawie programowej i tak jak w naszym kraju - dobór metod kształcenia i środków dydaktycznych leży w gestii nauczycieli. Zasadniczą różnicą jest jednak fakt, że kompetencje z przedsiębiorczości sprawdzane są na egzaminach końcowych w szwedzkich szkołach (Entrepreneurship Education..., 2012).

Zupełnie odmiennie wygląda edukacja w zakresie przedsiębiorczości na Łotwie. Przedsiębiorczość nie występuje bowiem w łotewskim systemie edukacji jako samodzielny przedmiot. Wybrane cele kształcenia w zakresie przedsiębiorczości realizowane są na I i II etapie edukacyjnym na przedmiotach: nauki społeczne, domowa ekonomia, technologie, sztuka wizualna i muzyka. Na III etapie edukacyjnym treści z zakresu edukacji z przedsiębiorczości zawarte są w podstawach programowych do przedmiotów: etyka, ekonomia, studia dziennikarskie, podstawy ekonomii biznesu. Wysoki poziom kształcenia w zakresie przedsiębiorczości na Łotwie jest spowodowany zaangażowaniem w jej rozwój ważnego podmiotu, którym jest Łotewska Agencja Inwestycji i Rozwoju (LIAA). Agencja ta jest odpowiednikiem polskiego PARP i organizuje liczne inicjatywy (projekty, warsztaty), również międzynarodowe, w których uczestniczą powszechnie łotewscy uczniowie. Na przykład w roku szkolnym 2010/2011 560 łotewskich uczniów uczestniczyło w programie rozwoju kompetencji przedsiębiorczych „Uczniowskie osiągnięcia młodzi łotewscy przedsiębiorcy". Corocznie uczniowie uczestniczą w przygotowaniach do olimpiady ekonomicznej - konkursu skierowanego do uczniów na III etapie kształcenia, do którego fazy przygotowawcze uczą łączenia teoretycznej wiedzy ekonomicznej z praktyką. Najciekawszym jest jednak projekt „Edukacja na rzecz przedsiębiorczości 
w Szwecji, Estonii, Łotwie i Finlandii” (SELF). Jest to wieloletni projekt rozwoju postaw przedsiębiorczych, w ramach którego uczestnicy mają stać się: „dobrymi uczniami, pewnymi siebie ludźmi, odpowiedzialnymi obywatelami i skutecznymi współpracownikami” (Entrepreneurship Education..., 2012: 53). W ramach trzyletniej fazy wdrożeniowej projektu w latach 2009-2011 w aż 60 szkołach podstawowych i gimnazjach rozwijano doświadczenia w zakresie umiejętności motywowania uczniów do wykazywania postawy przedsiębiorczej. Skale podejmowanych projektów są więc bardzo duże, przez co zdecydowana większość łotewskich uczniów jest weń zaangażowana, a uczestnictwo w projektach rozwijających przedsiębiorczą postawę stało się na Łotwie stałym elementem kształcenia w zakresie przedsiębiorczości młodzieży.

\section{Podsumowanie}

Analiza wskaźników służących do pomiaru przedsiębiorczości wykazała, że większość z nich skupia się wyłącznie na jednym aspekcie przedsiębiorczości, jakim jest zakładanie własnej działalności gospodarczej wbrew szerokiej współczesnej definicji przedsiębiorczości. Wyjątkiem są wskaźniki stworzone w ramach projektu GEM, które, choć niekompletne, to rozpatrywane łącznie, można uznać za wskaźniki przedsiębiorczości (TEA + EEA), zgodnie z jej definicją. Ich łączna analiza pozwoliła autorce na wyłonienie krajów o najbardziej przedsiębiorczej ludności i wykorzystanie tej informacji do analizy organizacji kształcenia w zakresie przedsiębiorczości w najbardziej przedsiębiorczych krajach, do których zaliczają się Estonia, Szwecja i Łotwa. Na podstawie analizy organizacji edukacji z przedsiębiorczości we wskazanych krajach autorka pragnie wskazać pięć wniosków i rozwiązań, które transferowane do polskiego systemu przyniosłyby poprawę jakości kształcenia przedsiębiorczości. Trzy rekomendacje dotyczą treści kształcenia. Po pierwsze, koniecznym jest wplatanie celów w zakresie kształtowania kompetencji przedsiębiorczych na różnych przedmiotach szkolnych już od najniższych etapów edukacyjnych. Po drugie, wprowadzanie na zajęciach z przedsiębiorczości treści merytorycznych z ekonomii (zarówno makroekonomii, jak i projektowania własnej działalności gospodarczej) jest zasadne dopiero na III etapie edukacyjnym. Po trzecie, dobrym dydaktycznie rozwiązaniem jest łączenie treściowe przedsiębiorczości z treściami z zakresu edukacji obywatelskiej. Prócz wskazanych sugestii dotyczących treści, czwartą wskazówką jest uwzględnianie sprawdzania efektów kształcenia w zakresie przedsiębiorczości na egzaminach końcowych, co zdecydowanie podnosi rangę przedmiotu. Ostatnim wnioskiem jest konieczność zaangażowania w podnoszenie poziomu edukacji z zakresu przedsiębiorczości instytucji i organizacji pozaedukacyjnych, w szczególności Polskiej Agencji Rozwoju Przedsiębiorczości.

Literatura

Referencess

Brzozowski, T. (2013). Status przedsiębiorczości w warunkach kryzysu edukacji. Przedsiębiorczość Edukacja, 9, 258-272.

Czerniachowicz, B. (2011). Uwarunkowania przedsiębiorczości korporacyjnej na przykładzie przedsiębiorstw z województwa zachodniopomorskiego. Studia i Prace Wydziału Nauk Ekonomicznych i Zarządzania, 21, 197-206. 
Czyżewski, A.B., Góralczyk-Modzelewska, M., Saganowska, E., Wojciechowska, M. (2001). Regionalne zróżnicowanie kapitału ludzkiego w Polsce. Warszawa: ZBSE, GUS.

Daszkiewicz, N. (2014). Education as a stimulating factor for entrepreneurship development. Horyzonty Wychowania, 13(26), 165-177.

Entrepreneurship Education at School in Europe National Strategies, Curricula and Learning Outcomes. (2012). Bruksela: EURYDICE.

Europe's Hidden Entrepreneurs Entrepreneurial Employee Activity and Competitiveness in Europe. (2016). Cologny/Geneva: The World Economic Forum.

Glinka, B., Gudkova, S. (2011). Przedsiębiorczość. Warszawa: Wolters Kluwer.

Global Entrepreneurship Monitor. Global report 2016/17. Pozyskano z: https://www.gemconsortium. org/report $/ 49812$

Gorzelak, G., Jałowiecki, B. (1996). Koniunktura gospodarcza i mobilizacja społeczna w gminach '95. Raport z I etapu badań, Studia Regionalne i Lokalne. Warszawa: EIRRiL.

Hryniewicz, J. (1998). Wymiary rozwoju gospodarczego gmin. Studia Regionalne i Lokalne, 25(58), $58-80$.

Internetowa encyklopedia PWN, hasło: przedsiębiorczość. Pozyskano z: https:/encyklopedia.pwn.pl/ haslo/przedsiebiorczosc;3963281.html

Karpacz, J. (2011) Kreatywność przedsiębiorców jako determinanta poszukiwania szans. Przegląd Organizacji, 1, 8-11.

Klonowska-Matynia, M., Palinkiewicz, J. (2013). Przedsiębiorczość w teorii ekonomicznej. Zeszyty Naukowe Wydziału Nauk Ekonomicznych Politechniki Koszalińskiej, 17, 29-40.

Kwiatkowski, S. (2000). Przedsiębiorczość intelektualna. Warszawa: PWN.

Lichtarski, J. (red.). (2003). Podstawy nauki o przedsiębiorstwie. Wrocław: Akademia Ekonomiczna.

Makieła, Z. (2007). Przedsiębiorczość w Polsce w układzie regionalnym. Przedsiębiorczość - Edukacja, $3,18-23$.

Maślanka, K. (2008). Kadra, której można zaufać. Cechy dobrego przedsiębiorcy ukształtowanego w systemie edukacji. Przedsiębiorczość - Edukacja, 4, 260-265.

Płaziak, M., Rachwał, T. (2015). „Przedsiębiorczy region” - zarys koncepcji w świetle analizy roli przedsiębiorczości w krajowej strategii rozwoju regionalnego. Przedsiębiorczość - Edukacja, 11, 37-49.

Rachwał, T. (2004). Podstawy przedsiębiorczości. Słownik dla liceum ogólnokształcącego, liceum profilowanego i technikum. Warszawa: Nowa Era.

Rachwał, T., (2005). Kształtowanie postaw uczniów na lekcjach podstaw przedsiębiorczości. Przedsiębiorczość - Edukacja, 1, 137-143.

Raczyk, A. (2009). Metody badania przedsiębiorczości oparte na rejestrze podmiotów gospodarki narodowej. Przedsiębiorczość - Edukacja, 5, 133-146.

Reynolds, P.D. (2000). National panel study of U.S. business startups: background and methodology. Databases for the Study of Entrepreneurship, 4, JAI/Elsevier Inc.

Sadowska, M. (2016). Edukacja w zakresie przedsiębiorczości w polskim systemie kształcenia oraz w państwach europejskich. W: M. Kosała, M. Urbaniec, A. Żur (red.), Współczesne dylematy badań nad przedsiębiorczością. Przedsiębiorczość międzynarodowa. vol. 2, 1. Kraków: Uniwersytet Ekonomiczny w Krakowie, 149-164.

Salamon, J. (2009). Przestrzenne zróżnicowanie wartości wskaźnika przedsiębiorczości na obszarach wiejskich województwa świętokrzyskiego. Infrastruktura i Ekologia Terenów Wiejskich, 5, 231-239.

Singer, S., Amoros, J.E., Moska, D. (2015). Global Entrepreneurship Monitor 2014 Global Report. London: GERA, 20.

Siuta-Tokarska, B., (2013). Zasadnicze aspekty pomiaru przedsiębiorczości. Organizacja i Kierowanie, 3, 92-105.

Skubiak, B. (2014). Edukacja jako czynnik wspierający rozwój gospodarczy. Implikacje dla Polski. Studia Ekonomiczne, 129, 195-203. 
Sołtys, J., Dorocki, S. (2016). Wskaźnik przedsiębiorczości w jednostkach terytorialnych Polski zróżnicowanie w czasie i przestrzeni. Przedsiębiorczość - Edukacja, 12, 18-35.

Sołoducho-Pelc, L. (2007). Czy przedsiębiorczości można się nauczyć - wpływ edukacji na rozwój przedsiębiorczości. W: P. Wachowiak, M. Dąbrowski, B. Majewski (red.), Kształtowanie postaw przedsiębiorczych a edukacja ekonomiczna. Warszawa: Fundacja Promocji i Akredytacji Kierunków Ekonomicznych, 218-223.

Strojny, J. (2010). Analiza potencjału przedsiębiorczego województwa podkarpackiego. Przedsiębiorczość - Edukacja, 6, 176-197.

Tarnawa, A., Węcławska, D., Zadura-Lichota, P., Zbierowski, P. (2016). Global Entrepreneurship Monitor Polska. Warszawa: PARP.

Wach, K. (2013). Edukacja na rzecz przedsiębiorczości wobec współczesnych wyzwań cywilizacyjno-gospodarczych. Przedsiębiorczość - Edukacja, 9, 246-257.

Zbierowski, P., Bratnicki, M. (2016). Zastosowanie metodologii Global Entrepreneurship Monitor do badania przedsiębiorczości organizacyjnej. Przedsiębiorczość i Zarządzanie, 6(I), 47-63.

Zioło, Z. (2007). Rola przedsiębiorczości w aktywizacji gospodarczej - zarys modelu. Przedsiębiorczość - Edukacja, 3, 10-17.

Kowalczyk, A., Wilk, W. (1994). Rola sektora prywatnego w gospodarce lokalnej w strefie podmiejskiej Warszawa - na przykładzie gmin Łomianki i Zielonka. Biuletyn KPZK PAN, 168, 145-164.

Agnieszka Świętek, dr nauk o Ziemi w zakresie geografii, absolwentka studiów z zakresu geografii Uniwersytetu Pedagogicznego w Krakowie w specjalności przedsiębiorczość i gospodarka przestrzenna. Adiunkt w Instytucie Geografii Uniwersytetu Pedagogicznego w Krakowie. Jej zainteresowania badawcze skupiają się wokół dwóch tematów: problematyki edukacji z zakresu geografii i przedsiębiorczości, a w szczególności procesu zakładania własnej działalności gospodarczej, wchodzenia młodych ludzi na rynek pracy oraz poziomu życia Romów w Polsce.

Agnieszka Świętek, $\mathrm{PhD}$ in geography, graduated from the Pedagogical University of Cracow with an MA degree in geography, specialisation in entrepreneurship and spatial planning. Asssociate professor at the Pedagogical University of Cracow, Institute of Geography. Her research interests focus on two different research themes: education in the field of geography and entrepreneurship, in particular the process of starting up own business, young people entering into the labour market and the quality of life of Roma in Poland.

\section{Adres/Address:}

Uniwersytet Pedagogiczny im. Komisji Edukacji Narodowej w Krakowie

Instytut Geografii

Zakład Dydaktyki Geografii

ul. Podchorążych 2

30-084 Kraków, Polska,

e-mail: aswietek@up.krakow.pl 